IZA DP No. 4169

Interpreting Degree Effects in the Returns to Education

Alfonso Flores-Lagunes

Audrey Light

May 2009 


\title{
Interpreting Degree Effects in the Returns to Education
}

\author{
Alfonso Flores-Lagunes \\ University of Florida \\ and IZA \\ Audrey Light \\ Ohio State University \\ Discussion Paper No. 4169 \\ May 2009 \\ IZA \\ P.O. Box 7240 \\ 53072 Bonn \\ Germany \\ Phone: +49-228-3894-0 \\ Fax: +49-228-3894-180 \\ E-mail: iza@iza.org
}

\begin{abstract}
Any opinions expressed here are those of the author(s) and not those of IZA. Research published in this series may include views on policy, but the institute itself takes no institutional policy positions.

The Institute for the Study of Labor (IZA) in Bonn is a local and virtual international research center and a place of communication between science, politics and business. IZA is an independent nonprofit organization supported by Deutsche Post Foundation. The center is associated with the University of Bonn and offers a stimulating research environment through its international network, workshops and conferences, data service, project support, research visits and doctoral program. IZA engages in (i) original and internationally competitive research in all fields of labor economics, (ii) development of policy concepts, and (iii) dissemination of research results and concepts to the interested public.
\end{abstract}

IZA Discussion Papers often represent preliminary work and are circulated to encourage discussion. Citation of such a paper should account for its provisional character. A revised version may be available directly from the author. 
IZA Discussion Paper No. 4169

May 2009

\section{ABSTRACT \\ Interpreting Degree Effects in the Returns to Education*}

Researchers often identify degree effects by including degree attainment $(D)$ and years of schooling (S) in a wage model, yet the source of independent variation in these measures is not well understood. We argue that $S$ is negatively correlated with ability among degreeholders because the most able graduate the fastest, while a positive correlation exists among dropouts because the most able benefit from increased schooling. Using data from the NLSY79, we find support for this explanation, and we reject the notion that the independent variation in $S$ and $D$ reflects reporting error.

JEL Classification: $\quad$ I21, J24, J31

Keywords: degree effects, returns to education

Corresponding author:

Alfonso Flores-Lagunes

Food and Resource Economics Department

University of Florida

P.O. Box 110240, IFAS

Gainesville, FL 32611-0240

USA

E-mail: alfonsofl@ufl.edu

\footnotetext{
* We thank Lung-fei Lee and Ian Walker for useful discussions, Stephen Bronars for comments on an earlier draft, and Alex Shcherbakov for providing excellent research assistance.
} 


\section{Introduction}

A central issue in labor economics is why credentialed workers (those with high school diplomas or college degrees) earn more than their non-credentialed counterparts. Such degree effects are consistent with sorting models of education (Arrow 1973, Spence 1973, Stiglitz 1975, Weiss 1983) in which employers use credentials to identify workers with desirable traits that cannot be directly observed. ${ }^{1}$ Degree effects are also generated by human capital models (Becker 1964, Card 1995, 1999) if good learners are the ones who stay in school long enough to earn credentials, or if "lumpiness" in the learning process leads to more skill acquisition in degree years than in preceding years (Chiswick 1973, Lange and Topel 2006). Despite difficulties in distinguishing between these two competing models, the "sorting versus human capital" debate has dominated the degree effects literature for over 30 years.

Largely overlooked in this debate is the role of functional form in the interpretation of degree effects. In the earliest empirical studies (Hungerford and Solon 1987, Taubman and Wales 1973), degree effects were identified by including a nonlinear function of years of school $(S)$ or categorical measures of degree attainment $(D)$ in a log-wage model. More recently, analysts have taken advantage of richer survey data to implement a different identification strategy: rather than include $S$ or $D$ in their wage models, they control for both $S$ and $D$ (Arkes 1999, Ferrer and Riddell 2002, Frazis 1993, Jaeger and Page 1996, Park 1999). The interpretation of the resulting degree effects-defined as the wage gap between credentialed and non-credentialed workers conditional on years of schooling-is the focus of our analysis.

When both $S$ and $D$ are included in a wage model, degree effects are identified because individuals with a given amount of schooling differ in their degree status or, stated differently, because years of schooling vary among individuals within a given degree category. We begin by considering how individuals' schooling decisions could generate the necessary variation in $S$ and D. Among orthodox human capital and sorting models, only Weiss's (1983) "sorting-cumlearning” model explains why $S$ and $D$ might vary independently. ${ }^{2}$ In Weiss’s model, individuals attend school for $S$ years and then take a test. High-ability individuals pass the test and earn a

\footnotetext{
${ }^{1}$ Following Weiss (1995), we use the term "sorting” to refer to both signaling and screening versions of the models.

${ }^{2}$ In other models (e.g., Arrow 1973, Becker 1964, Card 1999, Spence 1973, Stiglitz 1975) schooling attainment is a one-dimensional construct; whether it is measured as highest grade completed or highest degree received is left to survey designers and data analysts.
} 
degree, while low-ability individuals terminate their schooling without a degree. While this behavioral framework justifies the inclusion of $S$ and $D$ in a wage model, it is inconsistent with the fact that individuals take varying amounts of time to earn identical degrees.

The empirical literature provides a number of explanations for why "time to degree" might vary across individuals. After documenting that the time typically needed to earn a college degree increased significantly between the 1970s and 1990s, Bound et al. (2007), Bound and Turner (2007), and Turner (2004) consider such explanatory factors as (i) declines in student preparedness as more high school graduates were drawn into college; (ii) corresponding declines in course availability and other college resources that led to delays in degree completion; and (iii) credit constraints that led to increased in-school employment and enrollment interruptions among college students. Analyses of employment among high school and college students (Light 1999, 2001; Oettinger 1999; Parent 2006; Ruhm 1997; Stinebrickner and Stinebrickner 2003) and college transfer patterns (Hilmer 1997, 2000; Light and Strayer 2004; McCormick and Carroll 1997) provide additional insights into why students might vary in their time to degree completion.

To our knowledge, neither the theoretical nor empirical literature has considered a particular pattern that we find in the data: wages increase with years of school $(S)$ among both high school and college dropouts, but decrease in $S$ among both high school and college graduates. Given the lack of compelling explanations for the type of variation in $S$ and $D$ that would generate this particular pattern, we present a simple human capital model in which (i) individuals differ in ability, (ii) high-ability individuals acquire more skill than low-ability individuals during each year of school, (iii) degrees are awarded once a given skill threshold is reached, and (iv) lumpiness in learning causes individuals with varying ability levels to terminate their schooling upon crossing an identical degree threshold. In addition to predicting that highability individuals earn degrees and low-ability individuals do not, this model demonstrates how ability might be negatively correlated with time spent in school among degree-holders: everyone in this population reaches the same level of achievement, but the most able reach the threshold in the shortest time. Among individuals who do not earn a degree, however, those with the most ability stay in school the longest because they benefit from additional skill investments.

Our schooling model provides a rationale for including both $S$ and $D$ in the log-wage function. Moreover, it leads us to specify a wage function in which the $S$ slope varies across 
degree categories, and it predicts that the $S$ slope is negative for degree holders (e.g., college graduates) and positive for nondegree-holders (e.g., college dropouts). In contrast, earlier studies include independent dummy variables for each degree category $(D)$ and for schooling $(S)$ (Arkes 1999, Ferrer and Riddell 2002, Frazis 1993, Jaeger and Page 1996, Park 1999), or they specify a fully-interacted model with a dummy variable for every $S$-D cell (Jaeger and Page 1996, Park 1999). In the absence of an explicit theoretical justification for these functional forms, it is difficult to interpret the estimates. ${ }^{3}$

In estimating our log-wage model with data from the 1979 National Longitudinal Survey of Youth, we consider two additional issues. First, we acknowledge that the independent variation in $S$ and $D$ used for identification can arise from reporting errors as well as from the optimizing behavior described by our model. Because models that control for both $S$ and $D$ rely on variation in $S$ within each degree category, the estimates are more vulnerable to "noise" than are estimates that rely on the total variation in the data. To contend with measurement error, we reestimate our wage equations with $S$ and $D$ data that are judged to be "clean" to determine whether seemingly error-ridden observations are driving our results. While misreporting of both $S$ and $D$ has been widely explored (Ashenfelter and Krueger 1994, Black et al. 2000, Bound et al. 2001, Flores-Lagunes and Light 2006, Kane et al. 1999), estimates from the "clean” sample suggest that measurement error is not an important source of the independent variation in $S$ and $D$ used to identify degree effects.

Second, we argue that the most common measure of years of school-namely, highest grade completed-is not always the preferred measure. For degree holders, we wish to know how long it takes to earn the credential. However, time to completion is not fully captured by "highest grade completed" if the latter measures credits earned toward a degree-for example, high school graduates may report having completed grade 12 regardless of whether they earned their diploma in three, four, or five years. For this reason, “age at school exit” is our preferred measure of time spent in school for degree-holders. Among dropouts, where our goal is to measure the skill acquisition that takes place prior to school exit, the opposite is true: "highest

\footnotetext{
${ }^{3}$ In fact, existing estimates appear to be highly sensitive to functional form. When controlling for (noninteracted) dummy variables for each degree level and each year of schooling, Jaeger and Page (1996) predict a gap in log wages of 0.16 between bachelor's degree holders and college dropouts. When controlling for dummy variables for every $S-D$ cell, they predict the same gap in log wages (holding $S$ constant at 16) to be $75 \%$ higher.
} 
grade completed” (that is, progress made towards a degree) is likely to be a better measure than “age at school exit." In light of these concerns, we use both highest grade completed and age at school exit (conditional on work experience gained while in school) as alternative measures of $S$ in our wage models.

Our estimates reveal that the marginal effect of $S$ varies across degree categories in the systematic manner predicted by our model: each year of $S$ is associated with higher wages among high school and college dropouts, and with lower wages among high school and college

graduates. For the two dropout categories, the positive slope is larger in magnitude (ranging from 0.02 to 0.05 ) and more precisely estimated when $S$ is measured as highest grade completed than when $S$ is measured as age at school exit. For the two degree categories, the negative estimates (ranging from -0.002 to -0.03 ) become much more precise when we measure $S$ as age at school exit rather than as highest grade completed. The independent variation in $S$ and $D$ observed in the data appears to reflect important skill differences among individuals with a common degree status. By recasting degree effects as "time in school” effects conditional on $D$, we learn that dropouts who stay in school the longest are the most highly skilled of their type, as are graduates who complete their degrees in the shortest time.

\section{Schooling Model}

Our objective is to show time spent in school $(S)$ varies among individuals with a given degree status $(D)$ and, in particular, why $S$ is positively (negatively) correlated with ability among dropouts (graduates). We begin with a straightforward extension of Card's (1995, 1999) formalization of Becker's (1964) seminal model, in which individuals terminate their schooling when the marginal benefit equals the marginal cost. Becker (1964) and Card (1995, 1999) consider a single observed dimension-years of schooling $(S)$-in which to assess individuals: the more $S$ a worker has, the more skill and ability he is expected to embody. We augment this framework by assuming a degree is awarded to any individual who crosses a given skill threshold. We also assume that "lumpiness" in learning leads to a discontinuity in the human capital production function at the degree threshold. The discontinuity induces individuals with a range of abilities to terminate their schooling upon earning the degree-however, the more able among this group reach the threshold sooner than their less-able counterparts because they acquire skill at a faster rate. Individuals who lack the ability to earn a degree never face the discontinuity, and instead make their schooling decision precisely as described in the Becker and 
Card models. Thus, dropouts exhibit the familiar pattern in which more able individuals stay in school longer than less able individuals.

To formalize these arguments, we consider a group of individuals who are heterogeneous with respect to their innate ability, face no ex ante uncertainty about their ability, and are identical with respect to all cost-related factors such as discount rates and tastes. In addition, we assume that schools offer a single, identical degree and are essentially indistinguishable from one another-that is, we abstract from the role of school characteristics and programs of study in affecting how much a given individual will learn in a given amount of time. We make these simplifying assumptions in order to highlight the key features of our model. After presenting the model in 2.A, we discuss in 2.B the extent to which these "real world" complexities might influence students' schooling decisions and, in turn, the data that we analyze in subsequent sections.

\section{A. Effects of “Lumpiness" in Learning on Schooling Decisions}

We assume individual $i$ chooses years of schooling $\left(S_{i}\right)$ to maximize the utility function

$$
U\left(K_{i}, S_{i}\right)=K\left(S_{i}\right)-C\left(S_{i}\right)=g\left(S_{i} \mid A_{i}\right)-r S_{i},
$$

where $K_{i}$ and $A_{i}$ represent individual-specific acquired skill and innate ability, respectively, and $r$ is the discount rate. The function $K\left(S_{i}\right)=g\left(S_{i} \mid A_{i}\right)$ is the human capital production function that describes how each additional year of school translates into additional skill, and $C\left(S_{i}\right)=r S_{i}$ is the associated cost function. In contrast to Card's $(1995,1999)$ formulation, we include skill, rather than earnings, as an argument in the utility function; the individual seeks to maximize the discounted, present value of skill which, along with ability, determines his post-school earnings. ${ }^{4}$ The substitution of $K_{i}$ for earnings allows us to highlight the relationship between years of school and degree attainment, which we assume occurs whenever skill reaches the threshold $K^{D}$. Following Card (1995, 1999), we assume skill increases with $S$ at a decreasing rate, and that the marginal benefit of $S$ increases in $A$. However, we also assume that a discontinuity arises in $g\left(S_{i} \mid A_{i}\right)$ as the threshold $K^{D}$ is approached. This discontinuity only affects individuals whose ability is high enough to enable them to attain a degree, so we defer further discussion of this feature until we consider these individuals’ schooling decisions.

\footnotetext{
${ }^{4}$ We assume, as does Card (1995, 1999), that agents do not choose their optimal schooling level with an eye toward possible interactions between schooling attainment and post-school skill investments. Thus, they focus on the skill (and wages) that will potentially prevail at the outset of the career.
} 
In figure 1, we illustrate the schooling decisions of two individuals with relatively low levels of ability. Regardless of how long these individuals stay in school, their skill level does not get close enough to the threshold $K^{D}$ for "lumpiness" in learning to come into play. As a result, both individuals simply choose the schooling level at which the slope of their (continuous) production path equals the constant marginal cost $r$. For the individual with ability level $A_{1}$, this schooling level is $S_{1}$; for his counterpart with the higher ability level $A_{2}$, the optimal schooling level is $S_{2}$. In short, individuals in this range of the ability distribution-all of whom leave school without degrees — exhibit the familiar pattern (Becker 1964, Card 1995, 1999) of positive correlation between ability, years of school, and skill.

Next, we consider the schooling decisions of two individuals whose ability levels are sufficiently high to make degree attainment a possibility. Figure 2 shows that in the absence of any discontinuity, the individual with ability $A_{3}$ finds his optimum at point $\mathbf{b}$ ', while the individual with higher ability $A_{4}$ chooses a'. As each individual comes arbitrarily close to skill threshold $K^{D}$, however, his path shifts upward by a fixed amount. The upward shift in the function (shown by the solid lines) is caused by "lumpiness" in learning - that is, individuals experience a contemporaneous increment in their skill level once they complete a program of study. This feature of the learning process was first suggested by Chiswick (1973) to explain how degree attainment could be associated with a larger wage increment than nondegree years in the absence of job market signaling.

For the "type $A_{4}$ " individual, the discontinuity shown in figure 2 happens to occur at the skill level associated with $S_{4}$ years of school, which is the point at which he would terminate his schooling in the absence of a discontinuity. The individual reaches an optimum (point a) on the higher path, and leaves school with a degree after $S_{4}$ years. The discontinuity induces the lower ability individual to move to point $\mathbf{b}$ (i.e., leave school with a degree after $S_{3}$ years) rather than b'. More generally, individuals in this ability range can choose to stay in school longer in order to exploit the benefits of "lumpiness" in learning, but the most able among them earn their degrees the fastest.

Thus far, we have assumed that (i) "lumpiness" in learning produces a contemporaneous skill boost but does not affect the marginal benefit of $S$, and (ii) marginal cost is constant. If either assumption is relaxed, the most able individuals might opt to leave school sooner in response to the discontinuity - that is, they might terminate their schooling upon earning the 
degree rather than stay in school for a year or two beyond the degree. This scenario is shown in figure 3 , where we compare the "type $A_{3}$ " individual from figure 2 to a highly able "type $A_{5}$ " individual, where $A_{5}>A_{4}>A_{3}$. In the absence of a discontinuity, the individual with ability $A_{5}$ would proceed beyond skill level $K^{D}$ to point $\mathbf{a}^{\prime}{ }^{5} \quad$ If his production path not only shifts upward but also flattens, as shown in figure 3, he chooses point a. In other words, he opts not to proceed beyond the degree if the productivity burst associated with completing skill set $K^{D}$ is followed by a productivity slowdown as he begins acquiring the next skill set. Alternatively, if $r$ increases once $K^{D}$ is reached-because continued schooling is more difficult to fund or tastes change once a degree is obtained - the individual could also opt for point a. If such changes in the marginal benefit and/or marginal cost of school accompany "lumpiness" in learning, the result is that "type $A_{5}$ " individuals join the "type $A_{3}$ " and "type $A_{4}$ " individuals in leaving school upon crossing the degree threshold. This leads to even more variation in $S$ among individuals with identical degrees, while maintaining a negative relationship between $S$ and $A$.

\section{B. Additional Considerations}

Our simple extension of Card's (1995, 1999) schooling model demonstrates how particular patterns in the data might arise. While the pattern for dropouts (a positive relationship between $S$ and $A$ ) emerges directly from the Card model, the reverse pattern for graduates is generated because we assume "lumpiness" in learning in conjunction with the notion that degrees are awarded when a given skill level is reached. The notion that $S$ might represent something different for graduates than for dropouts-and, as we demonstrate in section 5 , the fact that the dropout-graduate contrast holds at both the high school and college level-appears not to have been analyzed elsewhere in the literature.

The literature has extensively explored the broader issue of why "time in school" and “time to degree” (especially college degree) vary across individuals. Becker (1964) and Card (1995, 1999) describe precisely how factors affecting both marginal benefit and marginal cost affect a given individual's schooling attainment. Bound et al. (2007), Bound and Turner (2007), and Turner (2004) consider a range of factors to explain why the timing of college degree attainment slowed during the 1970s and 1980s. Research on the employment of high school and

\footnotetext{
${ }^{5}$ Point a' in figure 3 corresponds to staying in school beyond the single degree program that we assume is available. Clearly, we could extend our framework to include a higher degree, in which case the production function would contain another discontinuity at a skill level beyond $K^{D}$; point a' would then correspond to dropping out of this higher degree program.
} 
college students (Light 1999, 2001; Oettinger 1999; Parent 2006; Ruhm 1997; Stinebrickner and Stinebrickner 2003) and college transfer patterns (Hilmer 1997, 2000; Light and Strayer 2004; McCormick and Carroll 1997) provide additional explanations for why years of school would vary across students. An exhaustive exploration of why $S$ would vary among individuals in a given degree/dropout category is beyond the scope of this study, but we consider a subset of issues that are potentially relevant to the interpretation of our findings.

In figures 1-2, we abstract entirely from individual heterogeneity in the marginal cost of school. While individual differences in preferences and funding opportunities unquestionably affect who stays in school the longest and who obtains a degree, these factors affect the empirical relationship between $S, D$, and wages only if they are related to labor market productivity. The key issue for our analysis is that financially constrained students are the most likely to accumulate in-school employment experience, which has been shown in some studies (e.g., Light 2001; Ruhm 1997) to have a direct effect on post-school earnings. Thus, variation in $S$ among individuals with a given degree status might reflect not only variation in ability, as assumed by our model, but variation in in-school experience as well. In estimating our wage models, we include detailed measures of both in-school and post-school work experience. This enables us to assess the (degree-specific) effect of $S$ on log-wages net of the effect of work experience.

By assuming that skill $\left(K^{D}\right)$ is identical among degree-holders, we also abstract from the fact that school characteristics and programs of study can affect how much is learned, conditional on student ability or time spent in school; an extensive literature explores the effects of school quality and college major on subsequent earnings (e.g., Altonji et al. 2005, Arcidiacono 2004, Brewer et al. 1999, Dale and Krueger 2002). A related issue is that college quality can affect $S$ if, for example, students at resource-constrained colleges are forced to delay their degree completion because of enrollment limits in courses needed to graduate. This phenomenon is shown by Bound et al. (2007) and Bound and Turner (2007) to be an important determinant of secular increases in time to college degree completion, and it can potentially affect cross-sectional variation in $S$ as well. Of course, "resource squeezes" on some college campuses cannot explain variation in $S$ among high school graduates as well as college graduates, nor can it explain why $S$ is wage enhancing among college dropouts. Nonetheless, we acknowledge that for college graduates, $S$ can be negatively correlated with college quality as well as individual ability. 
Our theoretical framework also makes the simplifying assumption that individuals face no uncertainty about their own abilities. Although this assumption is imposed more often than not in the schooling literature, uncertainty is worth discussing because it has been invoked by Chiswick (1973) and Lange and Topel (2006) to explain how degree effects could arise in the absence of job market signaling or "lumpiness" in skill acquisition. The argument is that individuals discover their true ability over time, and that the least able drop out of school in response to this discovery while the more able-who learn more than the less able during every year of school-remain in school to complete the degree. We acknowledge that individuals may discover their true ability while in school, and that the degree effects that we estimate in section 5 might reflect this type of selection-on-ability in addition to "lumpiness" in learning. ${ }^{6}$ However, neither of these existing studies helps us understand why $S$ and $D$ vary independently, or why the relationship between $S$ and ability differs for graduates and dropouts.

\section{Econometric strategy}

In section 2, we assumed that each individual chooses his years of school $(S)$ to maximize acquired skill $(K)$ which, in conjunction with innate ability $(A)$, determines his post-school “starting” wage. Employers cannot observe $K$ and $A$ directly, but they can observe degree status and $S$. Under the assumptions of our model, these factors fully describe ability and skill.

To incorporate these factors into an estimable wage model, we specify a fairly standard function that allows log-wages to evolve with experience, and schooling attainment to affect the intercept (but not the experience slope) of the age-earnings path (Mincer 1974). Our theoretical discussion calls for a functional form that allows the intercept of the log-wage path to increase with each successive degree category and to change with years of schooling within each category. Thus, we specify the following wage function:

$$
Y_{i}=\sum_{k=1}^{4} \alpha_{k} D_{k i}+\sum_{k=1}^{4} \delta_{k} D_{k i} S_{i}+\pi Z_{i}+u_{i},
$$

where $Y_{i}$ is the natural logarithm of the average hourly wage for individual $i, D_{k i}$ is a vector of

\footnotetext{
${ }^{6}$ The degree effects that we estimate can also reflect job market signaling. In fact, students might use both degree attainment and speed of completion as a multi-dimensional signal of their ability, as suggested by Groot and Oosterbeek (1994). In light of recent evidence (Lange 2007) that employers learn workers' true ability quite quickly — and that, as a result, signaling appears to play a relatively minor role-we focus on a strictly human capital explanation for the patterns seen in the data.
} 
dummy variables identifying degree categories, $S_{i}$ is time in school, $Z_{i}$ is a vector of additional covariates including cumulative labor market experience, and $u_{i}$ represents unobserved factors. In contrast to our earlier, simplifying assumption that workers earn a single degree upon reaching a given skill threshold, we now allow for two successive degrees. Specifically, $D_{k}$ distinguishes between high school dropouts $\left(D_{1}\right)$, high school graduates $\left(D_{2}\right)$, college dropouts $\left(D_{3}\right)$, and college graduates $\left(D_{4}\right) .^{7}$ Our model predicts that log-wages increase monotonically with each successive degree $\left(\alpha_{1}<\alpha_{2}<\alpha_{3}<\alpha_{4}\right)$, and that the effect of $S$ on these degree effects is positive for dropouts $\left(\delta_{1}>0, \delta_{3}>0\right)$ and negative for degree-holders $\left(\delta_{2}<0, \delta_{4}<0\right)$.

It is worth reiterating that our specification is not generally used in the degree effects literature. The orthodox approach—often dictated by a lack of independent data on $S$ and $D$-is to use a spline function or step function in $S$ and omit separate measures of $D$ (Belman and Heywood 1991, Hungerford and Solon 1987). Among studies that control for both $S$ and $D$, most include degree dummies and an independent (noninteracted) function of $S$ (Arkes 1999, Ferrer and Riddell 2002, Frazis 1993, Jaeger and Page 1996, Park 1999). This is equivalent to imposing the restriction $\delta_{1}=\delta_{2}=\delta_{3}=\delta_{4}$, although some studies relax our restriction that $Y$ is a linear function of $S$. Jaeger and Page (1996) and Park (1999) propose alternative specifications that allow for interactions between $S$ and $D$, but they use an extremely flexible functional form that includes a parameter for every year-of-schooling/degree combination. We propose equation (2) as the most parsimonious way to capture the $D$-S-specific intercepts that are consistent with our schooling model.

As long as the covariates $D_{k i}, S_{i}$, and $Z_{i}$ are complete and accurate representations of the factors that determine wages in the labor market, we can use ordinary least squares (OLS) to estimate the parameters in equation (2). While we maintain the assumption that our covariates are sufficient statistics for innate ability and acquired skill (and that wages are based on these factors), we cannot assume that our survey data are reported without error. Unfortunately, the instrumental variables and generalized method of moments estimators that are often used to account for measurement error in S or D (Ashenfelter and Krueger 1994, Black et al. 2000,

\footnotetext{
${ }^{7}$ The sample used to estimate equation (2) includes individuals who proceed beyond a college (bachelor's) degree to attend a wide variety of graduate programs. We experiment with combining these individuals into a fifth (and sixth) degree category and, alternatively, dropping them from the sample. We discuss these issues, as well as other issues related to our degree categories, in section 4.
} 
Flores-Lagunes and Light 2006, Kane et al. 1999) are inappropriate for our application because they allow only one covariate to be reported with error, and they require two, independent reports for the error-ridden variable. ${ }^{8}$ In the absence of a tractable estimation strategy that accounts for measurement error in both $S$ and $D$, we compare estimates from our primary sample to those from an alternative sample of seemingly "clean” responses to determine whether our results are sensitive to the inclusion of seemingly-erroneous data. ${ }^{9}$

The notation used in equation (2) implies that we use cross-sectional data for estimation and, in fact, a cross-section composed of each individual's post-school "starting wage" is our primary sample. We also use a panel sample consisting of annual wages reported by each sample member from school exit to the end of the observation period. We use ordinary least squares to estimate all models, but when using the panel sample we correct the standard errors for nonindependence across observations for a given worker. All models are estimated after transforming the data into deviations from sample-specific grand means. We describe each sample in section 4.

\section{Data}

\section{A. Sample Selection and Variable Definitions}

We use data from the 1979 National Longitudinal Survey of Youth (NLSY79) to estimate the wage functions described in section 3. The NLSY79 began in 1979 with a sample of 12,686 youth born in 1957-64, and it remains in progress today. Respondents were interviewed annually from 1979 to 1994 and biennially thereafter; 2004 is the last year for which data were available when we carried out the analysis. The NLSY79 is an ideal source of data for our analysis because respondents report their highest grade completed, dates of enrollment, and degree attainment; the survey also provides unusually detailed information on labor market activities, which enables us to net out the potentially confounding effects of work experience

\footnotetext{
${ }^{8}$ We have an independent report of high school graduation status for a subset of respondents for whom high school transcripts were collected, but the NLSY79 does not provide similar validation data for college attendance and degrees. Similarly, we have sibling-reported "highest grade completed" for respondents with in-sample siblings, but these reports pre-date final schooling attainment for many respondents.

${ }^{9} \mathrm{~A}$ potentially useful method for addressing measurement error in a categorical variable such as $D$ is the Lee and Porter (1984) switching regression model with imperfect regime (degree) classification. We also extend this model to our application, and find no evidence that degree reporting errors have an important effect on the estimates reported in section 5.
} 
gained while in school.

The first step in our data creation process is to identify each respondent's chronological sequence of diplomas and degrees received, along with the date when each credential was awarded. If an individual attended high school, college, or graduate school without earning a diploma or degree, we include his attendance spell and dropout date in the degree sequence. To construct this sequence, we use the following self-reported information: (i) whether the respondent holds a high school diploma or has passed the general educational development test (GED) at the date of the interview and, if so, the month and year of diploma/GED attainment; (ii) whether the respondent is enrolled in school at the time of the interview and, if not, the month and year of his last enrollment; (iii) the respondent's enrollment status in every month since the last interview; (iv) the month/year the respondent last attended his first, second, and third most recent colleges; and $(v)$ the type and month/year of receipt of as many as three diplomas and degrees or, in earlier survey years, of the highest degree. ${ }^{10}$ When identical diplomas or degrees are reported multiple times, we generally use the first-reported date; we resort to subsequentlyreported dates or to the enrollment timelines when information is missing.

We use this information to place each respondent into one of five categories: high school dropout, high school graduate, college dropout, college graduate (i.e., bachelor's degree recipient) or graduate degree recipient. Those respondents who complete their schooling without interruption are classified according to their "final" degree or dropout status. When individuals receive their schooling discontinuously, we assign them the dropout/degree status that prevails the first time they leave school for at least 18 months. We are limited in our ability to form post-bachelor's degree categories because our theoretical model assumes that individuals holding a given degree are homogeneous with respect to acquired skill, and we lack the sample size to define separate categories for holders of master's, professional, and doctoral degrees. In addition, we are unable to identify the degree programs being pursued by graduate school dropouts. Thus, we combine all graduate degree holders - who make up $2.7 \%$ of the sampleinto a single category $\left(D_{5}\right)$, but we do not include interactions between $D_{5}$ and $S$ in our wage model. Graduate school dropouts remain in our sample as college graduates if they are

\footnotetext{
${ }^{10}$ Monthly enrollment status questions (item iii) were asked in every interview except the first, and questions about degree types and dates (item $v$ ) were asked every year except 1985-87. All other sets of questions were included in every survey year, although many were only asked of respondents who indicated via a lead-in question whether they had attended school since the last interview.
} 
nonenrolled for at least 18 months between college and graduate school, and report a wage during the interim. As we demonstrate in section 5, our findings are unaffected by whether we categorize graduate students in this fashion, or eliminate them from the sample altogether; additional, unreported experiments, such as moving graduate school dropouts into a sixth category and adding interactions between $S$ and the post-college degree categories, also proved not to affect our inferences.

We choose not to segment the college dropout category into two-year college dropouts, two-year college graduates, and four-year college dropouts because these groups are conceptually indistinct, given the frequent use of two-year colleges as "stepping stones" to fouryear colleges (Hilmer 1997, Light and Strayer 2004, Rouse 1995). For example, we would hesitate to argue that a student who earns an associate's degree in two years and then spends one year at a four-year college differs in ability from a student who enrolls at a four-year college for three years. We substantiate this decision in section 5 by demonstrating that eliminating twoyear degree-holders from the sample does not significantly affect our estimates. We also show that our inferences do not depend on whether we treat individuals with a GED as high school dropouts (our default classification) or high school graduates.

After classifying each sample member with respect to highest degree, the second step in our data creation process is to identify the corresponding years of school. During each interview, respondents are asked to report their current "highest grade completed" if they have attended school since the last interview. We use the value reported during the first interview after the degree or dropout date as one measure of "time in school," which we now refer to as $S 1$. As an alternative measure of "time in school," we use the degree or dropout date in conjunction with the respondent's birth date to determine the age (measured to the nearest month) at which he or she left school; we refer to this variable as $S 2$.

The degree or dropout date used to define $S 2$ also serves as the career start date. With this date in hand, the next step in our data creation process is to select alternative samples of post-school wages. Our cross-sectional "starting wage" sample uses the first wage reported after the degree is awarded or the individual drops out of school. Our "all wages" sample includes that same wage, plus a maximum of one wage per year reported by the individual over the remainder of the panel, which ends when he reenrolls in school or is last observed. Given our strategy of allowing the intercept of the age-earning profile to depend on an individual's $D$-S 
combination, each wage sample has its own advantage. The "all wages" sample provides more data with which to fit the log-wage path. The "starting wage" sample contains relatively little variation in post-school work experience, which minimizes the possibility that $D$ and $S$ are correlated with unmeasured components of work experience due, perhaps, to the most able workers investing more intensively in on-the-job training than less able workers.

The final step in our data creation process is to define the remaining variables. Our dependent variable is the log of the average hourly wage, divided by the consumer price index (CPI-U). In addition to the time-invariant variables $D$ and $S$ (S1 and $S 2$ ), we include dummy variables identifying male, black, and Hispanic sample members; the default racial/ethnic category is individuals who are nonblack, non-Hispanic (“white”). The time-varying covariates include a set of dummy variables indicating the calendar year during which the wage is earned. We use the detailed work history information available in the NLSY79 to construct a measure of cumulative weeks worked from the $18^{\text {th }}$ birthday to the date when the wage is earned. In addition, we use the work experience reported by 16 and 17 year olds (available for respondents who are younger than 18 when the survey begins) to compute average work effort at age 16-17 as a fraction of work effort at age 18, by sex, race/ethnicity, and degree status. We then use these averages to assign every sample member a measure of predicted, early experience. We control for actual experience since age 18 and its square, along with predicted "early" (pre-age 18) experience in each of our wage models.

Our "starting wage" sample consists of a single observation for each of 11,712 individuals. While the original NLSY79 sample has 12,686 respondents, we eliminate 313 individuals for whom degree status, degree/dropout dates, and/or highest grade completed cannot be determined. We eliminate another 661 individuals because a post-school wage is not reported. The "all wages" sample contains between one and 21 observations for the same 11,712 individuals, for a total of 126,019 observations.

In addition to analyzing the entire "starting wage” sample of 11,712 individuals, we also examine a subsample in which the schooling and degree variables are judged to be "clean." To construct this subsample, we exploit the fact that degree attainment and highest grade completed should conform to certain institutional norms if respondents consider their progress toward a degree when reporting their highest grade completed. We expect high school dropouts to complete grade 11 or lower, high school graduates to complete grade 12, college dropouts to 
complete at least grade 12 but less than grade 16, and college graduates to complete grade 16 . In forming a "clean" sample, we eliminate individuals if their reported $S 1-D$ combination is sufficiently far from these expectations: we require $S 1 \leq 12, S 1=11-13, S 1=12-16, S 1=15-19$, and $S 1 \geq 16$ for individuals in the high school dropout, high school graduate, college dropout, college graduate, and graduate degree categories, respectively. This strategy eliminates roughly 3\% of observations in each high school and college category, and $1.3 \%$ of the graduate degree holders. The remaining sample consists of 11,277 individuals for whom the $S 1$ and $D$ data are not necessarily error-free, but are invariably less error-ridden than the data in the larger sample. By comparing estimates for our two samples, we can assess the effect of measurement error on the estimates. ${ }^{11}$ We do not construct a similar “clean” sample using our alternative variable S2 (age at school exit) because part-time and discontinuous enrollment often delay school exit. We control for these delays by including detailed experience measures in our wage model, but we lack clear expectations of the unconditional relationship between age at school exit and degree attainment.

\section{B. Summary Statistics}

Table 1 reports means and standard deviations for the variables used to estimate the wage models for both the "starting wage” and "all wages” samples. Table 2 contains a crosstabulation of "highest grade completed" $(S 1)$ and degree status $(D)$. It is clear from these distributions that $S 1$ varies considerably within $D$ category. A comparison of the coefficient of variation across columns reveals that $S 1$ varies far more within each dropout category than within each degree category; this conforms to the notion that $S 1$ measures progress made towards a degree and is therefore relatively homogenous among degree-holders. However, if we instead ask how often $S 1$ falls within the "expected” range for that particular degree category (less than 12 for high school dropouts, 12 for high school graduates, 13-15 for college dropouts, 16 for college graduates, and more than 16 for graduate degree holders) we find the most noise among the college-goers: $S 1$ is “as expected” for $97 \%$ of high school dropouts and $85 \%$ of high school graduates, but only $52 \%$ of college dropouts. These patterns suggest that there is ample variation

\footnotetext{
${ }^{11}$ Our strategy is less demanding of the data than those requiring validation data (e.g., Freeman 1984), and more flexible than those requiring relatively simple functional forms in order to jointly estimate measurement error and outcome models (Black et al. 2000, Flores-Lagunes and Light 2006, Kane et al. 1999).
} 
with which to identify independent wage effects of $S 1$ within each degree category-especially among dropouts-but that misreporting might be a particularly important source of this variation among college-goers.

Table 3 replicates table 2, except we now use “age at school exit” (S2) in place of highest grade completed. Using the coefficients of variation for comparison, it is clear that this alternative measure of time in school varies far more within degree category than does highest grade completed. While there is no "expected" age at which individuals complete each degree category, given that school exit dates can be extended by part-time or interrupted enrollment, it is interesting to note that only $86 \%$ of high school dropouts leave school by age 18 , only $53 \%$ of high school graduates earn their degrees at age 18, and only $32 \%$ of college graduates earn their degrees at age 22. In short, age at school exit diverges from " $S 1+6$ " as degree attainment increases. The estimates presented in section 5 will reveal whether the marginal wage effects of $S 1$ and $S 2$ differ once we condition on the in-school work experience that explains much of the divergence in these two measures.

\section{Findings}

Table 4 presents estimates of the degree-specific intercepts $\left(\alpha_{k}\right)$ and $D$-S interaction terms $\left(\delta_{k}\right)$ for a variety of wage model specifications, all of which use "highest grade completed" (S1) as our measure of time in school; additional parameter estimates for each specification are in table A1. We discuss these estimates before turning to the corresponding estimates in tables 5 and A2 in which $S 1$ is replaced with age at school exit (S2).

Column 1 of table 4 reports OLS estimates of a model that restricts the four degreespecific schooling coefficients to be equal. The column 1 specification is representative of much of the existing literature (Arkes 1999, Ferrer and Riddell 2002, Frazis 1993, Jaeger and Page 1996) in which the goal is simply to identify degree effects conditional on $S 1$. Based on the column 1 estimates, we would predict that the gap in log wages between high school graduates and high school dropouts is 0.005 (0.196-0.191), the corresponding gap among college graduates and dropouts is $0.16(0.462-0.301)$, and an additional year of school is associated with a $2 \%$ wage boost for all workers. ${ }^{12}$ When we allow the relationship between $S 1$ and log wages to vary

\footnotetext{
${ }^{12}$ When we reestimate the model after dropping blacks and Hispanics from the sample, the difference in predicted log-wage for high school dropouts and high school graduates increases to 0.054 . We do not report additional findings based on a sample of whites because they are very similar to what is shown in
} 
across degree categories (column 2), we estimate a much larger college degree effect than what is seen in column 1 (0.30 versus 0.16$)$, and we reject at a $1 \%$ significance level the null hypothesis that the estimated $S 1$ effects are equal across degree categories.

Moreover, the estimates in column 2 provide support for our theoretical argument that wages increase (decrease) with time in school among dropouts (graduates). The estimated $D-S$ coefficients are 0.019 and 0.039 for the high school and college dropout categories, respectively, and an imprecisely estimated -0.002 and -0.015 for the corresponding graduates categories. These point estimates are consistent with the notion that time in school is positively correlated with ability for dropouts but negatively correlated with ability for degree-holders. For the two degree categories, the imprecision of the estimated interaction terms is consistent with the evidence (table 2) that $S 1$ varies less for graduates than for dropouts. While the existing variation produces parameter estimates with the predicted signs, we believe "highest grade completed" is not the preferred measure of time in school for degree holders.

In columns 3-5 of table 4, we assess the effects on our OLS estimates of reclassifying certain degree types. In column 3, we move GED recipients from the high school dropout category to the high school graduate category. This increases the predicted log-wage gap associated with earning a high school degree but has relatively little effect on the estimated interaction effects. The estimated coefficient for the interaction between $S 1$ and $D_{2}$ reverses sign, but continues to be statistically insignificant. In column 4, we eliminate two-year degree holders from the sample rather than include them in the college dropout category. Eliminating these relatively high wage earners leads to a decrease in the estimated $S 1$ coefficient for college dropouts, but does not qualitatively affect our findings. In column 5, we eliminate individuals with post-college schooling from the sample. Again, this does not alter our inferences regarding the estimated effects of $S 1$ within each degree category.

Our next task is to assess the effects of measurement error on our estimates. In column 6 of table 4, we report estimates based on a "clean" sample that excludes observations where the reported $S-D$ combination is highly implausible (e.g., no high school diploma but $S 1=16$, or $S 1=12$ and a bachelor's degree). The differences between these estimates and the corresponding estimates in column 2 are not significantly different from zero. Despite the fact that the standard errors increase (as expected) when we switch to the clean sample, the estimated $S 1$ coefficients

tables 4-5 in all other respects. 
associated with the two degree categories actually become larger in absolute value. The "clean" estimates are consistent with the predictions of our model and with the notion that measurement error in $S$ and $D$ is relatively unimportant.

The final column of estimates in table 4 is based on our "all wages" sample. We maintain our original degree classifications and include seemingly error-ridden observations in this sample, so the column 7 estimates should be compared to the estimates shown in column 2 . Qualitatively, the column 7 estimates substantiate the evidence seen in column 2: predicted logwages increase with each successive degree category, and increase (decrease) with each additional year of school for dropouts (graduates). Quantitatively, all four estimated coefficients for the $S 1-D$ interactions are slightly larger in absolute value when we use the "all wages" sample than when we rely on the cross-sectional sample, although the college dropout category is the only one for which we reject the null hypothesis of pair-wise equality across models. ${ }^{13}$ This comparison suggests that $S$ might be weakly, positively correlated with unobserved factors that increase log-wages as the career unfolds. Such a correlation could arise for at least two reasons. First, although we implicitly argue that employers use $D$ and $S$ to discern worker productivity at the outset of the career, they may not completely learn their workers' true abilities for a few years, at which point they further reward the high-S (high ability) individuals. Altonji and Pierret (2001) and Lange (2007) provide evidence of this form of employer learning. Second, high-S (high ability) workers might gain more or "better" work experience that is not captured by our cumulative experience variable, or simply receive higher returns to on-the-job training. Because we do not allow the experience paths to differ across $S-D$ categories, such "fanning out” on the basis of ability would be subsumed by our estimated intercepts. In general, however, a switch to the "all wages" sample produces only minor changes to the point estimates, and does not significantly affect our key findings.

Next, we ask how our estimates change when we replace "highest grade completed" (S1) with "age at school exit” (S2) as our measure of time in school. Table 5 contains estimates for wage models that use this alternative measure, but are otherwise identical to the corresponding specifications in columns 1-5 and 7 of table 4; the column 6 estimates are omitted from table 5 because we lack priors on the unconditional relationship between degree and age at

\footnotetext{
${ }^{13}$ Proceeding in order from $D_{1}$ to $D_{4}$, the p-values for the tests of pair-wise equality across models are $0.21,0.21,0.02$ and 0.66 .
} 
school exit needed to select a “clean” sample.

In comparing the estimates shown in columns 1 and 2 of table 5, we again find that the data reject at a 1\% significance level the equal slope restriction imposed by specification 1. Using the preferred specification 2, we find that replacing "highest grade completed" with "age at school exit” has little effect on the estimated degree effects, although we now predict a slightly larger wage gap between college dropouts and high school graduates than what is seen in table 4. However, switching schooling measures has a significant effect on the estimated coefficients for the $S$-D interactions. In column 2 of table 4, we saw that the estimated $S 1$ coefficient is positive (and significant) for dropouts and negative (but insignificant) for graduates. The parameter estimates have the same signs in table 5, but now the estimated coefficients for both dropout categories are essentially zero (0.002-0.003 with standard errors at least as large as the parameter estimates) while the estimated coefficients for the two degree categories are precisely estimated and, in the case of high school graduates, larger in absolute value (-0.019 versus -0.002 in table 4). The estimates change very little when we reclassify GED recipients as high school graduates (column 3), eliminate two-year degree holders (column 4) or drop individuals with post-college schooling (column 5). When we switch to the "all wages" sample (specification 7), the estimated effect of $S 2$ continues to be zero for the two dropout categories, but becomes larger in absolute value for the two degree categories-although, using conventional significance levels, we reject the null hypothesis of equality across models for the college graduate category only.

To understand why our estimates are sensitive to the manner in which we measure time in school, it is useful to consider the two degree categories (high school and college graduates) separately from the two dropout categories. Even if holders of a given degree do not have identical levels of acquired skill, as assumed by our theoretical model, they complete similar programs and earn a similar number of credits. Consider one individual who earns a high school diploma at age 18, and another who earns the same diploma a year earlier. Both should report their highest grade completed as 12 to reflect the fact that they completed the final year of their program, but their reported school exit dates should differ because one of them completed the program more quickly than the other. In short, "age at school exit" is a more informative measure of what we wish to know about degree recipients-namely, the speed with which they complete a common grade or degree program. Therefore, it comes as no surprise that the estimated $S 2$ slopes in table 5 (based on "age at school exit”) predict that degree-holders earn 
approximately $2 \%$ less (for high school graduates) and 1-2\% less (for college graduates) for every extra year they take to graduate, whereas the corresponding estimates in table 4 (based on "highest grade completed") lack statistical significance.

In contrast, we believe "highest grade completed" is a more informative measure than "age at school exit" for both dropout categories. Our goal is to measure the amount of school completed (i.e., credits earned) in order to control for heterogeneity in skill among individuals with a given nondegree status. If reported accurately, "highest grade completed" is likely to be the preferred measure of schooling attainment for this purpose, given that future dropouts may "drag out" the time to school exit by failing courses, being truant, and otherwise spending time neither learning nor acquiring work experience. We believe the estimated slope coefficients in table 4, which imply that both high school (college) dropouts earn 2-3\% (3-5\%) more for every year spent in school, are preferred for assessing the effects of time spent in school among these individuals.

We can offer additional evidence to substantiate the argument that "age at school exit" is the preferred measure for degree-holders in the sense that it measures (inverse) innate ability, whereas "highest grade completed" is the preferred measure of skill and ability among dropouts. In 1980, over 90\% of NLSY79 respondents completed the Armed Services Vocational Aptitude Battery (ASVAB). NLSY79 users have access not only to individual ASVAB scores, but also to scores for the Armed Forces Qualification Test (AFQT), which are computed from respondents' scores on four parts of the ASVAB (word knowledge, paragraph comprehension, arithmetic reasoning, and mathematics knowledge). Because AFQT scores are considered to be good measures of pre-market skills (Neal and Johnson 1996), we assess their correlation with both measures of time spent in school for each degree-specific subsample. ${ }^{14}$ Among individuals in both degree categories, age-adjusted AFQT scores are strongly, negatively correlated with "age at school exit" but not with "highest grade completed." Within both dropout categories, ageadjusted AFQT scores are strongly, positively correlated with "highest grade completed," whereas the correlations with "age at school exit" are small and negative for college school dropouts and zero for high school dropouts.

\section{Concluding Comments}

\footnotetext{
${ }^{14}$ Respondents' ages ranged from 16 to 23 when the ASVAB was administered in 1980 , so we use deviations between raw scores and age-specific means.
} 
Our analysis begins with the observation that researchers often identify degree effects by controlling for both degree attainment $(D)$ and years of schooling $(S)$ in a wage model, despite the lack of compelling explanations for why these two measures of schooling attainment would vary independently. We argue that individuals with a given degree are roughly homogenous with respect to acquired skill, but because the more able can earn their degrees relatively quickly, $S$ is negatively correlated with innate ability among this population. Conversely, individuals who drop out of a given degree program vary considerably with respect to both innate ability and acquired skill, and $S$ is positively correlated with these traits. Our simple extension of Card's (1995, 1999) schooling model justifies the inclusion of both $D$ and $S$ in a wage model, and suggests that the effect of schooling on log-wages should be allowed to differ across degree categories.

In estimating wage models that control for both $D$ and $S$ using data from the 1979 National Longitudinal Survey of Youth, we identify a number of patterns that are consistent with our model. First, we find that the data resoundingly reject the restriction that the effect of "years of school" on log-wages is equal across degree categories-in other words, it is important to include degree dummies $(D)$ and $S-D$ interactions, rather than simply controlling for $S$ and $D$. Second, our estimates indicate that additional time in school is associated with higher wages for high school dropouts and college dropouts, but with lower wages for high school graduates and college graduates. Third, schooling effects for the two dropout categories are estimated more precisely when we use "highest grade completed" as the measure of S than when we use "age at school exit." For the two graduate categories, the opposite is true. Fourth, our estimates prove to be largely invariant to our attempts to account for measurement error in self-reported $S$ and $D$, which suggests that the independent variation in these two dimensions of schooling attainment is not dominated by “noise.”

The fact that our alternative measures of time spent in school ("age at school exit" and "highest grade completed”) appear to capture different information for degree holders and dropouts is a useful finding in its own right. We argue that high school and college graduates are expected to complete grades 12 and 16, respectively, and that, as a result, the age at which they earn their degrees is a more informative measure of ability than is their highest grade completed. Conversely, "highest grade completed" is a useful measure of progress made toward a degree among dropouts, whereas variation in "age at school exit” might reflect time spent neither 
gaining work experience (which we are able to control for separately) nor learning. Our estimates suggest that individuals within a given degree or dropout category vary considerably with respect to their ability and/or acquired skill, and that additional measures of schooling attainment are useful for explaining variation in post-school wages. While ours is not the first study to view schooling attainment as a multi-dimensional construct, we suspect there is far more to be learned by exploring heterogeneity in completion patterns among individuals with a given level of schooling attainment. 


\section{References}

Altonji, Joseph G., Todd E. Elder and Christopher R. Taber. 2005. "Selection on Observed and Unobserved Variables: Assessing the Effectiveness of Catholic Schools." Journal of Political Economy 113:151-184.

Altonji, Joseph G. and Charles Pierret. 2001. "Employer Learning and Statistical Discrimination.” Quarterly Journal of Economics 116:313-350.

Arcidiacono, Peter. 2004. "Ability Sorting and the Returns to College Major." Journal of Econometrics 121:343-375.

Arkes, Jeremy. 1999. "What Do Educational Credentials Signal and Why Do Employers Value Credentials?” Economics of Education Review 18:133-141.

Arrow, Kenneth J. 1973. "Higher Education as a Filter.” Journal of Public Economics 2:193216.

Ashenfelter, Orley and Alan Krueger. 1994. "Estimates of the Economic Returns to Schooling from a New Sample of Twins.” American Economic Review 84:1157-1173.

Becker, Gary. 1964. Human Capital; a Theoretical and Empirical Analysis, with Special Reference to Education. New York: Columbia University Press (for the National Bureau of Economic Research).

Belman, Dale and John S. Heywood. 1991. "Sheepskin Effects in the Returns to Education: An Examination of Women and Minorities.” Review of Economics and Statistics 73:720-24.

Black, Dan A., Mark C. Berger, and Frank A. Scott. 2000. "Bounding Parameter Estimates with Nonclassical Measurement Error.” Journal of the American Statistical Association 95:739748.

Bound, John, Charles Brown, and Nancy Mathiowetz. 2001. "Measurement Error in Survey Data.” In Handbook of Econometrics, Volume 5, ed. James J. Heckman and Edward E. Leamer. Amsterdam: Elsevier Science.

Bound, John, Michael F. Lovenheim and Sarah Turner. 2007. "Understanding the Increased Time to the Baccalaureate Degree.” University of Michigan, Population Studies Center Research Report 07-626.

Bound, John and Sarah Turner. 2007. "Cohort Crowding: How Resources Affect Collegiate Attainment.” Journal of Public Economics 91:877-899.

Brewer, Dominic J., Eric R. Eide and Ronald G. Ehrenberg. 1999. "Does It Pay to Attend an Elite Private College? Cross-Cohort Evidence on the Effects of College Type on Earnings.” Journal of Human Resources 34:104-123.

Card, David. 1995. "Earnings, Schooling, and Ability Revisited." In Research in Labor Economics, Volume 14, ed. Solomon Polachek. Greenwich, CT: JAI Press.

-. 1999. "The Causal Effect of Education on Earnings." In Handbook of Labor Economics, Volume 3, ed. Orley Ashenfelter and David Card. Amsterdam: Elsevier Science B.V.

Chiswick, Barry. 1973. "Schooling, Screening, and Income.” In Does College Matter? ed. 
Lewis Solmon and Paul Taubman. New York: Academic Press.

Dale, Stacy Berg and Alan B. Krueger. 2002. "Estimating the Payoff to Attending a More Selective College: An Application of Selection on Observables and Unobservables." Quarterly Journal of Economics 117:1491-1527.

Ferrer, Ana M. and Craig W. Riddell. 2002. "The Role of Credentials in the Canadian Labour Market.” Canadian Journal of Economics 35:879-905.

Flores-Lagunes, Alfonso and Audrey Light. 2006. "Measurement Error in Schooling: Evidence from Samples of Siblings and Identical Twins." Contributions to Economic Analysis and Policy 5, issue 1, article 14 ..

Frazis, Harvey. 1993. "Selection Bias and the Degree Effect.” Journal of Human Resources 28: 538-554.

Freeman, Richard B. 1984. "Longitudinal Analyses of the Effects of Trade Unions.” Journal of Labor Economics 2:1-26.

Groot, Wim and Hessel Oosterbeek. 1994. "Earnings Effects of Different Components of Schooling: Human Capital Versus Screening.” Review of Economics and Statistics 76:317321.

Hilmer, Michael J. 1997. "Does Community College Attendance Provide a Strategic Path to a Higher Quality Education?” Economics of Education Review 16: 59-68.

. 2000. "Does the Return to University Quality Differ for Transfer Students and Direct Attendees?” Economics of Education Review 19:47-61.

Hungerford, Thomas and Gary Solon. 1987. "Sheepskin Effects in the Returns to Education." Review of Economics and Statistics 69:175-77.

Jaeger, David A. and Marianne E. Page. 1996. "Degrees Matter: New Evidence on Sheepskin Effects in the Returns to Education.” Review of Economics and Statistics 78:733-740.

Kane, Thomas J., Cecilia Elena Rouse and Douglas Staiger. 1999. "Estimating Returns to Schooling When Schooling is Misreported.” NBER Working Paper 7235.

Lange, Fabian. 2007. “The Speed of Employer Learning.” Journal of Labor Economics 25:135.

Lange, Fabian and Robert Topel. 2006. "The Social Returns to Education and Human Capital.” In Handbook of the Economics of Education, Volume 1, ed. Eric Hanushek and Finis Welch. Amsterdam: North-Holland.

Lee, Lung-fei and Robert H. Porter. 1984. "Switching Regression Models with Imperfect Sample Separation Information with an Application to Cartel Stability.” Econometrica 52:391-418.

Light, Audrey. 1999. "High School Employment, High School Curriculum, and Post-School Wages.” Economics of Education Review 18:291-309.

_. 2001. "In-School Work Experience and the Returns to Schooling.” Journal of Labor Economics 19:65-93. 
Light, Audrey and Wayne Strayer. 2004. "Who Receives the College Wage Premium? Assessing the Labor Market Returns to Degrees and College Transfer Patterns.” Journal of Human Resources 39:746-773.

McCormick, Alexander C. and C. Dennis Carroll. 1997. "Transfer Behavior Among Beginning Postsecondary Students: 1989-94.” Statistical Analysis Report NCES97-266, National Center for Education Statistics. Washington, D.C.: U.S. Department of Education.

Mincer, Jacob. 1974. Schooling, Experience and Earnings. New York: Columbia University Press.

Neal, Derek A. and William R. Johnson. 1996. "The Role of Pre-Market Factors in Black-White Wage Differences.” Journal of Political Economy 104:869-895.

Oettinger, Gerald S. 1999. "Does High School Employment Affect High School Academic Performance?” Industrial and Labor Relations Review 43:136-161.

Parent, Daniel. 2006. "Work While in High School in Canada: Its Labour Market and Educational Attainment Effects." Canadian Journal of Economics 39:1125-1150.

Park, Jin-Heum. 1999. "Estimation of Sheepskin Effects Using the Old and the New Measures of Educational Attainment in the Current Population Survey." Economics Letters 62:237-240.

Rouse, Cecilia Elena. 1995. "Democratization or Diversion? The Effect of Community Colleges on Education Attainment.” Journal of Business and Economic Statistics 13:217-24.

Ruhm, Christopher. 1997. “Is High School Employment Consumption or Investment?” Journal of Labor Economics 15:735-776.

Spence, Michael. 1973. “Job Market Signaling.” Quarterly Journal of Economics 87: 355-374.

Stiglitz, Joseph E. 1975. “The Theory of 'Screening,' Education, and the Distribution of Income.” American Economic Review 65: 283-300.

Stinebrickner, Ralph and Todd Stinebrickner. 2003. "Working During School and Academic Performance.” Journal of Labor Economics 23:473-491.

Taubman, Paul J. and Terence J. Wales. 1973. "Higher Education, Mental Ability, and Screening.” Journal of Political Economy 81: 28-55.

Turner, Sarah. 2004. "Going to College and Finishing College: Explaining Different Educational Outcomes." In College Decisions: How Students Actually Make Them and How they Could, ed. Caroline M. Hoxby. Chicago: University of Chicago Press for NBER.

Weiss, Andrew. 1983. “A Sorting-cum-Learning Model of Education.” Journal of Political Economy 91: 420-442.

. 1995. "Human Capital vs. Signaling Explanations of Wages.” Journal of Economic Perspectives 9, no. 4:133-154. 


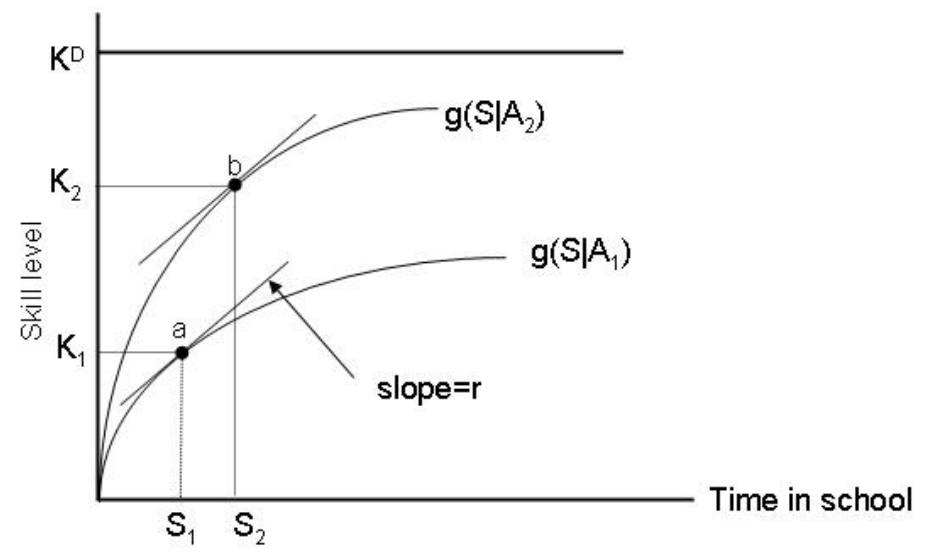

Fig. 1: Time in school for high ability $\left(A_{2}\right)$ and low ability $\left(A_{1}\right)$ dropouts 


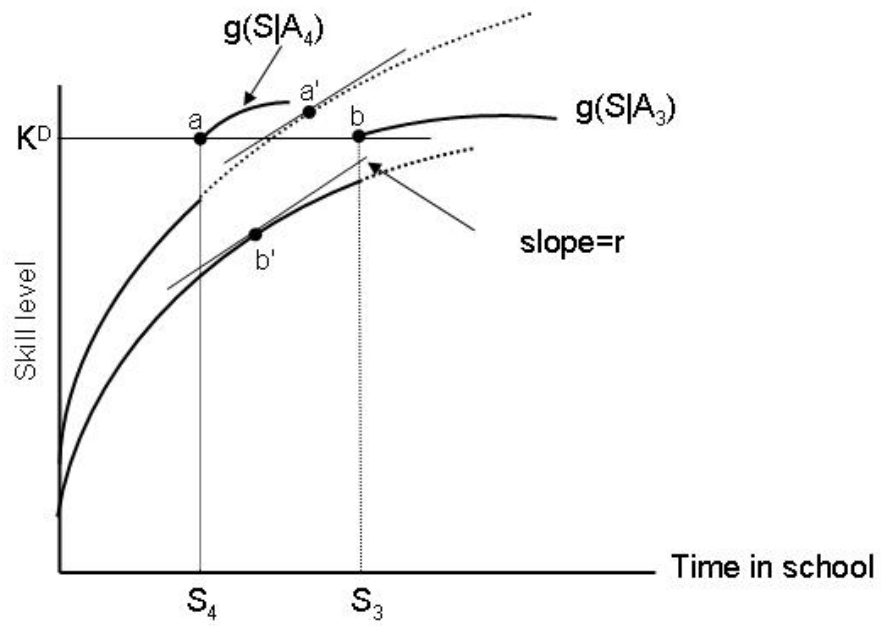

Fig. 2: Time in school for high ability $\left(A_{4}\right)$ and low ability $\left(A_{3}\right)$ graduates 


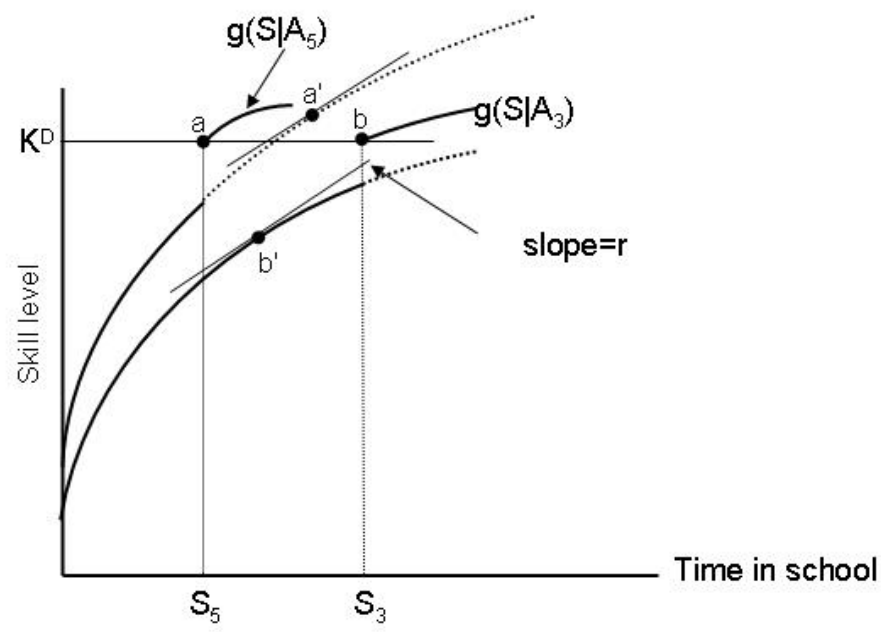

Fig. 3: Time in school for "higher" ability $\left(A_{5}\right)$ graduate who leaves school sooner in response to discontinuity 
Table 1: Summary Statistics for Selected Variables

\begin{tabular}{|c|c|c|c|c|}
\hline \multirow[b]{2}{*}{ Variable } & \multicolumn{2}{|c|}{$\begin{array}{c}\text { Starting } \\
\text { wages }\end{array}$} & \multicolumn{2}{|c|}{$\begin{array}{c}\text { All post- } \\
\text { school wages }\end{array}$} \\
\hline & Mean & S.D. & Mean & S.D. \\
\hline Ln(average hourly wage) & 1.81 & 1.09 & 2.23 & 2.02 \\
\hline Highest grade completed (S1) & 12.49 & 2.44 & 12.40 & 2.36 \\
\hline Age at school exit (S2) & 21.10 & 5.13 & 20.12 & 3.70 \\
\hline \multicolumn{5}{|l|}{ Degree } \\
\hline High school dropout $\left(D_{1}\right)$ & \multicolumn{2}{|l|}{.17} & \multicolumn{2}{|l|}{.17} \\
\hline High school diploma $\left(D_{2}\right)$ & \multicolumn{2}{|l|}{.33} & \multicolumn{2}{|l|}{.37} \\
\hline College dropout $\left(D_{3}\right)$ & \multicolumn{2}{|l|}{.34} & \multicolumn{2}{|l|}{.32} \\
\hline College graduate $\left(D_{4}\right)$ & \multicolumn{2}{|l|}{.13} & \multicolumn{2}{|l|}{.13} \\
\hline Graduate degree $\left(D_{5}\right)$ & \multicolumn{2}{|l|}{.03} & \multicolumn{2}{|l|}{.01} \\
\hline Actual experience $^{\mathrm{a}}$ & 2.74 & 4.02 & 9.21 & 6.88 \\
\hline Early experience $^{\mathrm{b}}$ & .07 & .23 & .08 & .27 \\
\hline 1 if male & \multicolumn{2}{|l|}{.51} & \multicolumn{2}{|l|}{.53} \\
\hline 1 if black & \multicolumn{2}{|l|}{.25} & \multicolumn{2}{|l|}{.27} \\
\hline 1 if Hispanic & \multicolumn{2}{|l|}{.16} & \multicolumn{2}{|l|}{.18} \\
\hline Number of observations & \multicolumn{2}{|c|}{11,712} & \multicolumn{2}{|c|}{126,019} \\
\hline Number of individuals & \multicolumn{2}{|c|}{11,712} & \multicolumn{2}{|c|}{11,712} \\
\hline
\end{tabular}

${ }^{\text {a }}$ Hours worked from $18^{\text {th }}$ birthday to date wage was earned, divided by 2,000.

${ }^{\mathrm{b}}$ Hours worked between $16^{\text {th }}$ and $18^{\text {th }}$ birthday. 
Table 2: Highest Grade Completed by Highest Degree Received

\begin{tabular}{|c|c|c|c|c|c|c|}
\hline $\begin{array}{l}\text { Highest } \\
\text { grade } \\
\text { completed }\end{array}$ & $\begin{array}{c}\text { High } \\
\text { school } \\
\text { dropout }\end{array}$ & $\begin{array}{c}\text { High } \\
\text { school } \\
\text { graduate }\end{array}$ & $\begin{array}{l}\text { College } \\
\text { dropout }\end{array}$ & $\begin{array}{l}\text { College } \\
\text { graduate }\end{array}$ & $\begin{array}{c}\text { Graduate } \\
\text { degree }\end{array}$ & $\begin{array}{c}\text { All } \\
\text { degree } \\
\text { levels }\end{array}$ \\
\hline $2-8$ & $\begin{array}{c}544 \\
(26.8)\end{array}$ & $\begin{array}{c}45 \\
(1.2)\end{array}$ & $\begin{array}{c}4 \\
(0.1)\end{array}$ & $\begin{array}{c}1 \\
(0.1)\end{array}$ & & $\begin{array}{l}592 \\
(5.1)\end{array}$ \\
\hline $9-10$ & $\begin{array}{l}1,005 \\
(49.8)\end{array}$ & $\begin{array}{l}213 \\
(5.5)\end{array}$ & $\begin{array}{c}34 \\
(0.9)\end{array}$ & & & $\begin{array}{l}1,252 \\
(10.7)\end{array}$ \\
\hline 11 & $\begin{array}{c}415 \\
(20.5)\end{array}$ & $\begin{array}{c}311 \\
(8.0)\end{array}$ & $\begin{array}{c}38 \\
(1.0)\end{array}$ & & & $\begin{array}{c}764 \\
(6.5)\end{array}$ \\
\hline 12 & $\begin{array}{c}45 \\
(2.2)\end{array}$ & $\begin{array}{l}3,295 \\
(84.8)\end{array}$ & $\begin{array}{l}1,644 \\
(41.7)\end{array}$ & $\begin{array}{c}7 \\
(0.5)\end{array}$ & $\begin{array}{c}1 \\
(0.3)\end{array}$ & $\begin{array}{l}4,992 \\
(42.6)\end{array}$ \\
\hline 13 & $\begin{array}{c}3 \\
(0.2)\end{array}$ & $\begin{array}{c}14 \\
(0.4)\end{array}$ & $\begin{array}{c}897 \\
(22.8)\end{array}$ & $\begin{array}{c}5 \\
(0.3)\end{array}$ & $\begin{array}{c}1 \\
(0.3)\end{array}$ & $\begin{array}{l}920 \\
(7.9)\end{array}$ \\
\hline 14 & $\begin{array}{c}4 \\
(0.2)\end{array}$ & $\begin{array}{c}8 \\
(0.2)\end{array}$ & $\begin{array}{c}940 \\
(23.8)\end{array}$ & $\begin{array}{c}24 \\
(1.6)\end{array}$ & $\begin{array}{c}1 \\
(0.3)\end{array}$ & $\begin{array}{c}977 \\
(8.3)\end{array}$ \\
\hline 15 & $\begin{array}{c}2 \\
(0.1)\end{array}$ & $\begin{array}{c}2 \\
(0.1)\end{array}$ & $\begin{array}{c}214 \\
(5.4)\end{array}$ & $\begin{array}{c}112 \\
(7.2)\end{array}$ & $\begin{array}{c}1 \\
(0.3)\end{array}$ & $\begin{array}{c}331 \\
(2.8)\end{array}$ \\
\hline 16 & $\begin{array}{c}4 \\
(0.2)\end{array}$ & & $\begin{array}{c}138 \\
(3.5)\end{array}$ & $\begin{array}{l}1,227 \\
(79.3)\end{array}$ & $\begin{array}{c}3 \\
(1.0)\end{array}$ & $\begin{array}{l}1,372 \\
(11.7)\end{array}$ \\
\hline 17 & & & $\begin{array}{c}19 \\
(0.5)\end{array}$ & $\begin{array}{c}131 \\
(8.5)\end{array}$ & $\begin{array}{c}39 \\
(12.6)\end{array}$ & $\begin{array}{c}189 \\
(1.6)\end{array}$ \\
\hline $18-20$ & & & $\begin{array}{c}19 \\
(0.5) \\
\end{array}$ & $\begin{array}{c}40 \\
(2.6) \\
\end{array}$ & $\begin{array}{c}264 \\
(85.2) \\
\end{array}$ & $\begin{array}{r}323 \\
(2.8) \\
\end{array}$ \\
\hline $\begin{array}{l}\text { All grades } \\
\text { [\% row total] }\end{array}$ & $\begin{array}{l}2,020 \\
{[17.3]}\end{array}$ & $\begin{array}{l}3,888 \\
{[33.2]}\end{array}$ & $\begin{array}{l}3,947 \\
{[33.7]}\end{array}$ & $\begin{array}{l}1,547 \\
{[13.2]}\end{array}$ & $\begin{array}{c}310 \\
{[2.7]}\end{array}$ & 11,712 \\
\hline $\begin{array}{l}\text { Coefficient } \\
\text { of variation }\end{array}$ & 18.3 & 6.6 & 9.8 & 4.6 & 6.1 & 19.5 \\
\hline
\end{tabular}

Note: The table shows the number of sample members reporting each $S-D$ combination. Percents of column totals are in parentheses. 
Table 3: Age at School Exit by Highest Degree Received

\begin{tabular}{|c|c|c|c|c|c|c|}
\hline $\begin{array}{c}\text { Age at } \\
\text { school exit }\end{array}$ & $\begin{array}{c}\text { High } \\
\text { school } \\
\text { dropout }\end{array}$ & $\begin{array}{c}\text { High } \\
\text { school } \\
\text { graduate }\end{array}$ & $\begin{array}{l}\text { College } \\
\text { dropout }\end{array}$ & $\begin{array}{l}\text { College } \\
\text { graduate }\end{array}$ & $\begin{array}{c}\text { Graduate } \\
\text { degree }\end{array}$ & $\begin{array}{c}\text { All } \\
\text { degree } \\
\text { levels } \\
\end{array}$ \\
\hline $12-16$ & $\begin{array}{c}833 \\
(41.2)\end{array}$ & $\begin{array}{c}49 \\
(1.3)\end{array}$ & $\begin{array}{c}1 \\
(0.0)\end{array}$ & & & $\begin{array}{l}883 \\
(7.5)\end{array}$ \\
\hline 17 & $\begin{array}{c}510 \\
(25.3)\end{array}$ & $\begin{array}{l}206 \\
(5.3)\end{array}$ & $\begin{array}{c}4 \\
(0.1)\end{array}$ & $\begin{array}{c}1 \\
(0.1)\end{array}$ & & $\begin{array}{c}721 \\
(6.2)\end{array}$ \\
\hline 18 & $\begin{array}{c}402 \\
(19.9)\end{array}$ & $\begin{array}{l}2,053 \\
(52.8)\end{array}$ & $\begin{array}{c}111 \\
(2.8)\end{array}$ & $\begin{array}{c}6 \\
(0.4)\end{array}$ & & $\begin{array}{l}2,572 \\
(22.0)\end{array}$ \\
\hline 19 & $\begin{array}{l}160 \\
(7.9)\end{array}$ & $\begin{array}{c}990 \\
(25.5)\end{array}$ & $\begin{array}{c}623 \\
(15.8)\end{array}$ & $\begin{array}{c}1 \\
(0.1)\end{array}$ & & $\begin{array}{l}1,774 \\
(15.2)\end{array}$ \\
\hline 20 & $\begin{array}{c}38 \\
(1.9)\end{array}$ & $\begin{array}{c}268 \\
(6.9)\end{array}$ & $\begin{array}{c}726 \\
(18.4)\end{array}$ & $\begin{array}{c}65 \\
(4.2)\end{array}$ & & $\begin{array}{l}1,097 \\
(9.4)\end{array}$ \\
\hline 21 & $\begin{array}{c}14 \\
(0.7)\end{array}$ & $\begin{array}{c}79 \\
(2.0)\end{array}$ & $\begin{array}{c}573 \\
(14.5)\end{array}$ & $\begin{array}{c}143 \\
(9.2)\end{array}$ & $\begin{array}{c}1 \\
(0.3)\end{array}$ & $\begin{array}{c}810 \\
(6.9)\end{array}$ \\
\hline 22 & $\begin{array}{c}8 \\
(0.4)\end{array}$ & $\begin{array}{c}46 \\
(1.2)\end{array}$ & $\begin{array}{c}388 \\
(9.8)\end{array}$ & $\begin{array}{c}492 \\
(31.8)\end{array}$ & & $\begin{array}{c}934 \\
(8.0)\end{array}$ \\
\hline 23 & $\begin{array}{c}2 \\
(0.1)\end{array}$ & $\begin{array}{c}40 \\
(1.0)\end{array}$ & $\begin{array}{c}324 \\
(8.2)\end{array}$ & $\begin{array}{c}275 \\
(17.8)\end{array}$ & $\begin{array}{c}3 \\
(1.0)\end{array}$ & $\begin{array}{c}644 \\
(5.5)\end{array}$ \\
\hline $24+$ & $\begin{array}{c}53 \\
(2.6) \\
\end{array}$ & $\begin{array}{l}157 \\
(4.0)\end{array}$ & $\begin{array}{l}1,197 \\
(30.3)\end{array}$ & $\begin{array}{c}564 \\
(36.5) \\
\end{array}$ & $\begin{array}{c}306 \\
(98.7) \\
\end{array}$ & $\begin{array}{l}2,277 \\
(19.4)\end{array}$ \\
\hline $\begin{array}{l}\text { All ages } \\
{[\% \text { row total] }}\end{array}$ & $\begin{array}{l}2,020 \\
{[17.3]}\end{array}$ & $\begin{array}{l}3,888 \\
{[33.2]}\end{array}$ & $\begin{array}{l}3,947 \\
{[33.7]}\end{array}$ & $\begin{array}{l}1,547 \\
{[13.2]}\end{array}$ & $\begin{array}{l}310 \\
{[2.7]}\end{array}$ & 11,712 \\
\hline $\begin{array}{l}\text { Coefficient } \\
\text { of variation }\end{array}$ & 16.5 & 11.8 & 21.8 & 13.9 & 16.2 & 24.3 \\
\hline
\end{tabular}

Note: The table shows the number of sample members reporting each $S-D$ combination. Percents of column totals are in parentheses 
Table 4: OLS Estimates of Alternative Wage Models Using “Highest Grade Completed” as Measure of Time in School

\begin{tabular}{|c|c|c|c|c|c|c|c|}
\hline \multirow[b]{3}{*}{ Variable } & \multicolumn{6}{|c|}{ Cross-sectional sample of starting wages } & \multirow{2}{*}{$\begin{array}{c}\text { All } \\
\text { post- } \\
\text { school } \\
\text { wages }\end{array}$} \\
\hline & & & $\begin{array}{l}\text { Move } \\
\text { GEDs }\end{array}$ & $\begin{array}{c}\text { Drop } \\
\text { 2-year } \\
\text { degrees }\end{array}$ & $\begin{array}{c}\text { Drop } \\
\text { post- } \\
\text { college }\end{array}$ & $\begin{array}{c}\text { Clean } \\
\text { sample }\end{array}$ & \\
\hline & (1) & (2) & (3) & (4) & (5) & (6) & (7) \\
\hline \multicolumn{8}{|l|}{ Degree category } \\
\hline High school dropout $\left(D_{1}\right)$ & $\begin{array}{c}.191 \\
(.021)\end{array}$ & $\begin{array}{r}.186 \\
(.026)\end{array}$ & $\begin{array}{r}.169 \\
(.028)\end{array}$ & $\begin{array}{r}.147 \\
(.025)\end{array}$ & $\begin{array}{r}.168 \\
(.024)\end{array}$ & $\begin{array}{r}.175 \\
(.027)\end{array}$ & $\begin{array}{l}1.050 \\
(.021)\end{array}$ \\
\hline High school graduate $\left(D_{2}\right)$ & $\begin{array}{c}.196 \\
(.014)\end{array}$ & $\begin{array}{r}.180 \\
(.015)\end{array}$ & $\begin{array}{r}.185 \\
(.014)\end{array}$ & $\begin{array}{r}.145 \\
(.014)\end{array}$ & $\begin{array}{r}.166 \\
(.013)\end{array}$ & $\begin{array}{r}.145 \\
(.021)\end{array}$ & $\begin{array}{l}1.064 \\
(.014)\end{array}$ \\
\hline College dropout $\left(D_{3}\right)$ & $\begin{array}{c}.301 \\
(.014)\end{array}$ & $\begin{array}{r}.293 \\
(.015)\end{array}$ & $\begin{array}{r}.293 \\
(.015)\end{array}$ & $\begin{array}{r}.252 \\
(.015)\end{array}$ & $\begin{array}{r}.264 \\
(.015)\end{array}$ & $\begin{array}{r}.296 \\
(.015)\end{array}$ & $\begin{array}{l}1.197 \\
(.014)\end{array}$ \\
\hline College graduate $\left(D_{4}\right)$ & $\begin{array}{c}.462 \\
(.021)\end{array}$ & $\begin{array}{c}.594 \\
(.057)\end{array}$ & $\begin{array}{c}.594 \\
(.057)\end{array}$ & $\begin{array}{c}.565 \\
(.058)\end{array}$ & $\begin{array}{c}.612 \\
(.074)\end{array}$ & $\begin{array}{c}.623 \\
(.078)\end{array}$ & $\begin{array}{l}1.610 \\
(.050)\end{array}$ \\
\hline Graduate degree $\left(D_{5}\right)$ & $\begin{array}{c}.615 \\
(.037)\end{array}$ & $\begin{array}{c}.742 \\
(.031)\end{array}$ & $\begin{array}{c}.742 \\
(.031)\end{array}$ & $\begin{array}{c}.717 \\
(.031)\end{array}$ & & $\begin{array}{c}.741 \\
(.031)\end{array}$ & $\begin{array}{c}1.716 \\
(.029)\end{array}$ \\
\hline Time in school (S1) & $\begin{array}{c}.021 \\
(.004)\end{array}$ & & & & & & \\
\hline$S 1$ interacted with & & & & & & & \\
\hline High school dropout $\left(D_{1}\right)$ & & $\begin{array}{c}.019 \\
(.006)\end{array}$ & $\begin{array}{c}.016 \\
(.006)\end{array}$ & $\begin{array}{c}.020 \\
(.006)\end{array}$ & $\begin{array}{c}.020 \\
(.006)\end{array}$ & $\begin{array}{c}.016 \\
(.006)\end{array}$ & $\begin{array}{c}.028 \\
(.005)\end{array}$ \\
\hline High school graduate $\left(D_{2}\right)$ & & $\begin{array}{l}-.002 \\
(.009)\end{array}$ & $\begin{array}{c}.006 \\
(.007)\end{array}$ & $\begin{array}{l}-.002 \\
(.009)\end{array}$ & $\begin{array}{l}-.002 \\
(.009)\end{array}$ & $\begin{array}{l}-.012 \\
(.026)\end{array}$ & $\begin{array}{l}-.014 \\
(.007)\end{array}$ \\
\hline College dropout $\left(D_{3}\right)$ & & $\begin{array}{c}.039 \\
(.006)\end{array}$ & $\begin{array}{c}.039 \\
(.006)\end{array}$ & $\begin{array}{c}.028 \\
(.007)\end{array}$ & $\begin{array}{c}.040 \\
(.006)\end{array}$ & $\begin{array}{c}.040 \\
(.007)\end{array}$ & $\begin{array}{c}.053 \\
(.005)\end{array}$ \\
\hline College graduate $\left(D_{4}\right)$ & & $\begin{array}{l}-.015 \\
(.015)\end{array}$ & $\begin{array}{l}-.015 \\
(.015)\end{array}$ & $\begin{array}{l}-.016 \\
(.015) \\
\end{array}$ & $\begin{array}{l}-.014 \\
(.018)\end{array}$ & $\begin{array}{l}-.028 \\
(.022) \\
\end{array}$ & $\begin{array}{l}-.023 \\
(.013)\end{array}$ \\
\hline Number of observations & 11,712 & 11,712 & 11,712 & 10,900 & 10,999 & 11,277 & 126,019 \\
\hline
\end{tabular}

Note: Column 3 moves GED recipients from category $D_{1}$ to $D_{2}$. Column 4 omits two-year degree recipients from category $D_{3}$. Column 5 omits graduate school dropouts from category $D_{4}$ and all graduate degree recipients. Column 6 omits observations with highly implausible S-D combinations (see text for details). Column 7 uses annual wage observations reported from school exit to the observation period's end; for this sample, standard errors are corrected for nonindependence across observations for a given individual. Additional parameter estimates are reported in table A1. 
Table 5: OLS Estimates of Alternative Wage Models Using “Age at School Exit” as Measure of Time in School

\begin{tabular}{|c|c|c|c|c|c|c|}
\hline \multirow[b]{3}{*}{ Variable } & \multicolumn{5}{|c|}{ Cross-sectional sample of starting wages } & \multirow{2}{*}{$\begin{array}{c}\text { All } \\
\text { post- } \\
\text { school } \\
\text { wages }\end{array}$} \\
\hline & & & $\begin{array}{l}\text { Move } \\
\text { GEDs }\end{array}$ & $\begin{array}{c}\text { Drop } \\
\text { 2-year } \\
\text { degrees }\end{array}$ & $\begin{array}{l}\text { Drop } \\
\text { post- } \\
\text { college }\end{array}$ & \\
\hline & (1) & (2) & (3) & $(4)$ & (5) & $(7)$ \\
\hline \multirow{2}{*}{$\begin{array}{l}\text { Degree category } \\
\text { High school dropout }\left(D_{1}\right)\end{array}$} & & & & & & \\
\hline & $\begin{array}{r}.114 \\
(.019)\end{array}$ & $\begin{array}{r}.133 \\
(.023)\end{array}$ & $\begin{array}{r}.120 \\
(.027)\end{array}$ & $\begin{array}{r}.091 \\
(.022)\end{array}$ & $\begin{array}{c}.131 \\
(.021)\end{array}$ & $\begin{array}{c}.981 \\
(.020)\end{array}$ \\
\hline High school graduate $\left(D_{2}\right)$ & $\begin{array}{r}.176 \\
(.014)\end{array}$ & $\begin{array}{r}.136 \\
(.016)\end{array}$ & $\begin{array}{r}.148 \\
(.015)\end{array}$ & $\begin{array}{r}.107 \\
(.015)\end{array}$ & $\begin{array}{c}.134 \\
(.015)\end{array}$ & $\begin{array}{l}1.030 \\
(.015)\end{array}$ \\
\hline College dropout $\left(D_{3}\right)$ & $\begin{array}{r}.312 \\
(.014)\end{array}$ & $\begin{array}{r}.299 \\
(.014)\end{array}$ & $\begin{array}{r}.300 \\
(.014)\end{array}$ & $\begin{array}{r}.253 \\
(.015)\end{array}$ & $\begin{array}{c}.282 \\
(.014)\end{array}$ & $\begin{array}{c}1.218 \\
(.014)\end{array}$ \\
\hline College graduate $\left(D_{4}\right)$ & $\begin{array}{c}.537 \\
(.018)\end{array}$ & $\begin{array}{c}.560 \\
(.019)\end{array}$ & $\begin{array}{l}.562 \\
(.019)\end{array}$ & $\begin{array}{c}.533 \\
(.020)\end{array}$ & $\begin{array}{c}.567 \\
(.023)\end{array}$ & $\begin{array}{l}1.586 \\
(.018)\end{array}$ \\
\hline Graduate degree $\left(D_{5}\right)$ & $\begin{array}{c}.740 \\
(.031)\end{array}$ & $\begin{array}{l}.713 \\
(.035)\end{array}$ & $\begin{array}{l}.712 \\
(.035)\end{array}$ & $\begin{array}{c}.667 \\
(.035)\end{array}$ & & $\begin{array}{l}1.705 \\
(.029)\end{array}$ \\
\hline Time in school (S2) & $\begin{array}{l}-.002 \\
(.002)\end{array}$ & & & & & \\
\hline \multicolumn{7}{|l|}{$S 2$ interacted with } \\
\hline High school dropout $\left(D_{1}\right)$ & & $\begin{array}{c}.003 \\
(.004)\end{array}$ & $\begin{array}{c}.001 \\
(.005)\end{array}$ & $\begin{array}{c}.002 \\
(.004)\end{array}$ & $\begin{array}{l}.006 \\
(.004)\end{array}$ & $\begin{array}{c}.009 \\
(.005)\end{array}$ \\
\hline High school graduate $\left(D_{2}\right)$ & & $\begin{array}{l}-.019 \\
(.003)\end{array}$ & $\begin{array}{l}-.013 \\
(.003)\end{array}$ & $\begin{array}{l}-.019 \\
(.003)\end{array}$ & $\begin{array}{l}-.017 \\
(.003)\end{array}$ & $\begin{array}{l}-.023 \\
(.003)\end{array}$ \\
\hline College dropout $\left(D_{3}\right)$ & & $\begin{array}{c}.002 \\
(.002)\end{array}$ & $\begin{array}{c}.002 \\
(.002)\end{array}$ & $\begin{array}{l}-.001 \\
(.002)\end{array}$ & $\begin{array}{c}.006 \\
(.002)\end{array}$ & $\begin{array}{c}.001 \\
(.001)\end{array}$ \\
\hline College graduate $\left(D_{4}\right)$ & & $\begin{array}{l}-.010 \\
(.003) \\
\end{array}$ & $\begin{array}{l}-.010 \\
(.003) \\
\end{array}$ & $\begin{array}{l}-.011 \\
(.003)\end{array}$ & $\begin{array}{l}-.013 \\
(.003)\end{array}$ & $\begin{array}{l}-.024 \\
(.003)\end{array}$ \\
\hline Number of observations & 11,712 & 11,712 & 11,712 & 10,900 & 10,999 & 126,019 \\
\hline
\end{tabular}

Note: Column 3 moves GED recipients from category $D_{1}$ to $D_{2}$. Column 4 omits two-year degree recipients from category $D_{3}$. Column 5 omits graduate school dropouts from category $D_{4}$ and all graduate degree recipients. Column 6 uses annual wage observations reported from school exit to the observation period's end; standard errors are corrected for nonindependence across observations for a given individual. Additional parameter estimates are reported in table A2. 
Table A1: Additional Estimates for Specifications in Table 4 ("Highest grade completed" is used as measure of time in school)

\begin{tabular}{|l|ccccccc|}
\hline Variable & $(1)$ & $(2)$ & $(3)$ & $(4)$ & $(5)$ & $(6)$ & $(7)$ \\
\hline Actual experience & .058 & .058 & .058 & .057 & .062 & .057 & .062 \\
& $(.003)$ & $(.003)$ & $(.003)$ & $(.004)$ & $(.003)$ & $(.003)$ & $(.001)$ \\
Actual experience squared & -.001 & -.001 & -.001 & -.001 & -.002 & -.001 & -.001 \\
& $(.000)$ & $(.000)$ & $(.000)$ & $(.000)$ & $(.000)$ & $(.000)$ & $(.000)$ \\
Early experience & .016 & .016 & .014 & .015 & .010 & .014 & .002 \\
& $(.024)$ & $(.024)$ & $(.022)$ & $(.023)$ & $(.023)$ & $(.024)$ & $(.015)$ \\
1 if male & .172 & .172 & .172 & .177 & .175 & .173 & .177 \\
& $(.008)$ & $(.008)$ & $(.008)$ & $(.009)$ & $(.009)$ & $(.009)$ & $(.007)$ \\
1 if black & -.063 & -.065 & -.063 & -.063 & -.063 & -.063 & -.100 \\
& $(.010)$ & $(.010)$ & $(.010)$ & $(.010)$ & $(.010)$ & $(.010)$ & $(.008)$ \\
1 if Hispanic & -.000 & -.002 & -.001 & .002 & .000 & .002 & .014 \\
& $(.012)$ & $(.012)$ & $(.012)$ & $(.012)$ & $(.012)$ & $(.012)$ & $(.010)$ \\
$\sigma_{u}^{2}$ & .200 & .200 & .200 & .198 & .191 & .199 & .274 \\
\hline
\end{tabular}

Note: Each specification also includes calendar year dummies. 
Table A2: Additional Estimates for Specifications in Table 5 (“Age at school exit” is used as measure of time in school)

\begin{tabular}{|l|cccccc|}
\hline Variable & $(1)$ & $(2)$ & $(3)$ & $(4)$ & \multicolumn{1}{c}{$(5)$} & $(7)$ \\
\hline Actual experience & .061 & .061 & .061 & .061 & .062 & .062 \\
Actual experience squared & $(.004)$ & $(.004)$ & $(.004)$ & $(.004)$ & $(.004)$ & $(.001)$ \\
& -.001 & -.001 & -.001 & -.001 & -.002 & -.001 \\
Early experience & $(.000)$ & $(.000)$ & $(.000)$ & $(.000)$ & $(.000)$ & $(.000)$ \\
& .020 & .022 & .010 & .021 & .015 & .005 \\
1 if male & $(.024)$ & $(.024)$ & $(.022)$ & $(.023)$ & $(.023)$ & $(.016)$ \\
& .171 & .171 & .171 & .177 & .174 & .177 \\
1 if black & $(.008)$ & $(.008)$ & $(.008)$ & $(.009)$ & $(.009)$ & $(.007)$ \\
& -.063 & -.061 & -.061 & -.059 & -.061 & -.095 \\
1 if Hispanic & $(.010)$ & $(.010)$ & $(.010)$ & $(.010)$ & $(.010)$ & $(.008)$ \\
& -.005 & -.002 & -.003 & .011 & -.001 & .016 \\
$\sigma_{u}^{2}$ & $(.012)$ & $(.012)$ & $(.012)$ & $(.012)$ & $(.012)$ & $(.010)$ \\
& .201 & .200 & .200 & .198 & .191 & .274 \\
\hline
\end{tabular}

Note: Each specification also includes calendar year dummies. 